\title{
AEROMAGNETIC MAP OF STAUNTON AND VICINITY, VIRGINIA
}

\author{
By \\ Robert W. Johnson, Jr. and Joel S. Watkins
}
GEOPHYSICAL INVESTIGATIONS
MAP GP-414

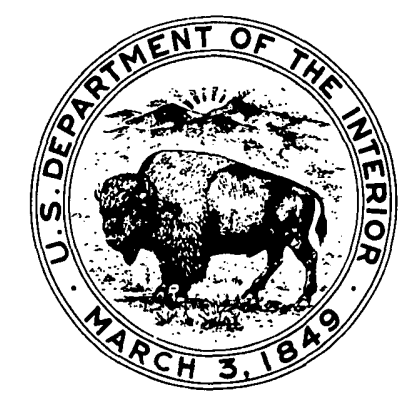

PUBLISHED BY THE U. S. GEOLOGICAL SURVEY

WASHINGTON, D.C. 